\title{
Resilience in the Context of Pandemics and Disasters: A Framework for Public Governance, Ecosystem Innovation, Co-creation, and Co-production
}

\author{
Greiciele Macedo Morais ${ }^{1}$, Henrique Cordeiro Martins ${ }^{1} \&$ Valdeci Ferreira dos Santos ${ }^{1}$ \\ ${ }^{1}$ FUMEC University, Minas Gerais, Brazil \\ Correspondence: Greiciele Macedo Morais, PhD, Business Administration, FUMEC University, Minas Gerais, \\ Brazil.
}

Received: April 19, 2021

Accepted: May 20, 2021

Online Published: January 5, 2022

doi:10.5430/ijba.v13n1p15

URL: https://doi.org/10.5430/ijba.v13n1p15

\begin{abstract}
This article, through a literature review, explores evidence that public governance positively influences and stimulates the innovation ecosystem, the co-creation, and co-production of resilience in communities that are victims of disasters, shocks, and even pandemic disasters, such as COVID-19. Disaster scenarios of all kinds cause millions of damage to society. The negative impacts of these contexts disasters, shocks, catastrophes, even if pandemic, such as COVID-19, can be greater or lesser, depending on the dysfunctions of governance and the negative barriers to the creation of public policies consistent with the capacity for resilience. Thus, the possible solution to this scenario may be based on public governance, if the pubic governance is instituted in an organized, integrated, and articulated manner. For this purpose, a theoretical conceptual framework of value creation is proposed through public governance that values and stimulates the innovation ecosystem, the co-creation, co-production of value, and a static, hierarchical, and linear structural vision. There is theoretical evidence that public governance can promote resilience in communities that are victims of disasters, shocks, pandemics or disturbances, through an ecosystem of innovation, co-creation and co-production of value. In this regard, at the end of this article, a theoretical-conceptual framework for creating public value is proposed.
\end{abstract}

Keywords: governance, co-production, co-creation, resilience, ecosystem, innovation

\section{Introduction}

For decades, disasters have caused damage to millions of people (Nkwunonwo, Whitworth, Baily, \& Inkpen, 2014). In this context, natural disasters stand out for their severity and destructive power, but also for the frequency that they occur. Disasters that are directly related to human actions, such as the pandemic of COVID -19, are also of great concern. These unnatural disasters, depending on their dimensions, can cause damage as serious as natural disasters, or more (Barasa, 2018; World Health Organization (WHO), 2021).

Besides the tragic figures for the fatal victims of COVID-19 disease, it is noted that the disaster must also be considered from the perspective of local, regional, and national and international resilience. This crisis suggests in the near future, the accumulation of other severe consequences of the pandemic and the need for governments to act tirelessly on structural and solid plans to deal with them. A study conducted in Bangladesh by Rahman (2020) signals and demonstrates the negative association between the fragile health system and the government's capacity to deal with the pandemic, revealing the existence of poor governance. Governance in this context is of significant relevance in the face of the weaknesses that COVID-19 will leave beyond interrupting lives, such as the socioeconomic impact of the paralysis, the rise in prices of basic needs, difficulties and formal education, which together can lead to other serious socioeconomic crises and other diseases (Rahman, 2020).

Poor governance, political inertia, corruption, disproportionate power, weak awareness and participation of the population, lack of data and poor knowledge about risks need to be addressed (Nkwunonwo et al., 2014; Wanie \& Ndi, 2018). This context needs to give rise to good governance, with adequate risk assessment and communication, guaranteeing the basics for people in the most vulnerable situations (Rahman, 2020), prioritizing a fair and equitable sharing of resources and knowledge to mitigate other risks, generating confidence and resilience in the affected communities (Berger, Evans, Phelan, \& Silverman, 2020). 
The mitigation of risks arising from disasters, with a focus on protecting the most vulnerable population, requires the integration of actions at the global, national, regional and local levels. This to aggregate information, knowledge, financing, provision of services, medicines and equipment, health professionals, research and innovation (Legido-Quigley, Mateos-García, Campos, Gea-Sánchez, Muntaner, \& McKee, 2020), leadership and science-based and timely decision-making (Djalante, Shaw \& DeWit, 2020). Governments must be able to act collectively to develop and strengthen resilience in coping, fighting and adapting to the new pandemic context and future scenarios (Barasa, 2018; Rahman, 2020).

Good governance must redraw the boundaries between the roles of the state and society. The various actors in society (citizens, scientific and technological institutions, research centers, public and private institutions, the third sector and others) can add resources and knowledge when collaborating with the government. They can also contribute by sharing ideas, experiences and proposals to solve the problems that plague society (Rhodes, 1997; Lynn, 2010; Ehnert, Kern, Borgström, Gorissen, Maschmeyer, \& Egermann, 2018). It is the role of governance to stimulate this environment of cooperation between the actors for solutions in complex and catastrophic contexts. The participatory and inclusive environment encourages co-creation and co-production of public value, the development and strengthening of resilience (Vignieri \& Bianchi, 2017; Wanie \& Ndi, 2018; Ricciardelli, Manfredi, \& Antonicelli, 2018).

For these reasons, this article through the literature review seeks to examine the theoretical evidence on the assumption that local public governance is capable of generating better results for and with society, through the influence, articulation, and modeling of an innovation ecosystem that values and stimulates the co-creation and co-production of local resilience in the context of pandemics, disasters or disruptions. Based on that, this work proposes a theoretical-conceptual framework of public, dynamic, and cooperative governance, with the function of mediating the innovation ecosystem, the co-creation, and co-production of resilience in communities affected by severe disruptions.

\section{Methodological Procedures}

A literature review was adopted as the methodological path. The databases verified were the Web of Science Core Collection and Google Scholar. In the Web of Science Core Collection database, from the base period (1945-2020), the parameters were used: articles that contain in the abstract, title, or keywords, the combination of the keywords "Public Governance" AND "co-production" AND "co-creation". On this basis, 29 results were found and sorted by relevance in a higher number of citations. All abstracts were read and selected according to the adherence to the theme. Ten articles had no direct relation to the topic and were excluded. The other 19 articles were read, and their theoretical contributions were extracted. The combination "innovation ecosystem" AND "Public Governance" was applied, which did not show results. The adjustment for "innovation ecosystem" AND "Public Sector" returned eight articles in the sample.

At the same time, google scholar adopted the first advanced search with at least one of the keywords "co-production" OR "co-creation" AND "Public Governance" returning 1,750 results and 222 results with the combination "innovation ecosystem" AND "public governance," in any part of the articles published in the English language, in the period (2015-2020). Considering the vast material found on the subject, we applied the content analysis of the titles, abstracts, conclusions, selecting only the articles adherent to the subject, without conceptual or ideological repetitions, and preferably from more cited authors. Literature reviews naturally run the risk of bias due to the author's narrative (Bilotta, Milner, \& Boyd, 2014). Therefore, in this article, we ensure that all statements are supported by plural references, from different currents of thought, in order to avoid bias in the theoretical scientific statements.

\section{Literature Review}

This topic aims to provide the reader with a review of the literature on the relationship between public governance and the resilience of the process, if mediated by the innovation ecosystem, by co-creation and co-production of public value, focused on the context of catastrophes, such as the pandemic crisis.

\subsection{Local Resilience: A Public Governance Assignment?}

Resilience is a process by which an entity, individual, community, or organization maintains its functionality base when confronted with severe disruptions, outbreaks, or random emergencies to the existential threat. It refers to the ability of a system or population to survive a disaster, which is so violent that it is impossible to resist it (Ricciardelli et al., 2018). 
Ensuring an engineered environment resilient to disasters, shocks, and disruptions is a complex job (Malalgoda, Amaratunga \& Haigh, 2013). Several fronts discussed its complexity, such as shocks caused by natural disasters, terrorism, pandemics, economic recession, failures, and serious human error that represent potential threats to the organizations' continued operations (Bhamra, Dani \& Burnard, 2011). These events are composed of elements that challenge any precise definition and then become confused with a retrospective stimulated by the event itself, with which individuals, communities, organizations, and nations begin to reflect on what they should have done or prepared to do to avoid further damage (Alexander, 2003).

All the complex and multiple dimensions of resilience, which include technical, organizational, social, and economic facets, must be considered in building resilient communities (Manyena, 2006). Resilience is linked to the empowerment and involvement of society, which requires communities to have an inherent capacity for self-organization to manage resources at any time, as well as the ability to adapt and learn to make decisions (Ricciardelli et al., 2018).

Resilience policies need to incorporate the concept of risk management into their organizational governance systems as an effort towards more sustainable communities. Resilience policies bring together flexibility, inclusiveness, integration, reflexivity, resourcefulness, robustness and redundancy to accommodate disruptions (Ricciardelli et al., 2018), through strategies, plans, regulations and practical development schedules (Wanie \& Ndi, 2018).

Resilience policies also depend on integration between policy and practice, through the emphasis on management effectiveness and strategic processes that shape and influence collaborative attitudes, community self-organization, sustainability practices, adaptive capacity, resilience, recovery, robustness, persistence, preparedness, and innovation. These elements configure resilience as a systemic capacity that involves the environment, the locality, and population in facing change, survival, adaptation, and growth, regardless of the type of chronic or recurrent stress they experience (Ricciardelli et al., 2018).

Resilience is not guided by universal, top-down, centralized recommendations defined by experts and endorsed by policymaking bodies as a hierarchical myth. Nor can priority be given to market forces and the individualistic nature. Resilience must be achieved in a consultative manner from its evaluation phase to action. This requires adaptive governance, management, and multi-stakeholder engagement as key elements in examining and developing a shared understanding, recognition, legitimacy, and future vision of social, environmental, economic, and political systems (Chohan \& Jacobs, 2017).

Organizations, governance structures, and governments, at any of their levels, need to be more aware of the improvements and benefits of public policies and resilience mechanisms for community security, public order, and systemic stability (Rodin, 2014; Ricciardelli et al., 2018). In practice, like any other theory, the governance structure also requires some care not to become just rhetoric (Saito-Jensen, 2015; Sanders, A. J.P., Hyldmo, H. S., Prasti, R. D., Ford, R. M., Larson, A. M., \& Keenan, R. J., 2017; Myers, Larson, Ravikumar, Kowler, Yang, \& Trench, 2018).

\subsection{Public Governance: Challenges and Opportunities for Innovation}

The issue of public governance is dynamic in its form of adaptation and change. The governance structure, due to its dynamism, can be improved, adapted, and adjusted to reality, maintaining its final purpose of generating better results for the target audience (Frederickson, 2005). The term public governance emerged in the mid-1887s (Campbell, 2014) representing the evolution of new and traditional public administration (Vignieri \& Bianchi, 2017), as a response to the strict focus on the administration of rules, the imperfection of hierarchical organization and the equal arrangements for all public institutions (Rhodes, 1997; Osborne, 2006; Van Thiel, Pollitt, \& Homburg, 2007; Moore, 2014; Castelnovo, Misuraca \& Savoldelli, 2016; Loeffler \& Bovaird, 2018; Galuszka, 2019).

Governance evolved significantly in the 1970s and 1980s (Rhodes, 1997) and became a term of dominance and power (Osborne, 2010), with a range of concepts and characteristics. It now faces much criticism on some dysfunctions such as disparity of concepts and uses in an imprecise way, anti-government, anti-bureaucratic sense and excessive focus and superiority in the market (Kernaghan, Borins \& Marson, 2000; Frederickson, 2005; Osborne, 2010), democratic deficits (Hirst, 2000), public-private partnerships, privatization (Milward \& Provan, 2000), failures to deal with diversity, inclusion, and democracy (Frederickson, 2005; Kernaghan et al., 2000). However, public governance advanced in the last decade, motivated and compelled by a globalized, technological, digital, innovative, and multi-action scenario. Public governance now follows a more holistic approach to decisions and the implementation of public policies for value creation (Castelnovo et al., 2016).

The contribution of governance lies in its value as an organizing structure and in its capacity to support changes to create value and innovation, using essential public values (Stoker, 1998). Governance is a vehicle through which 
public values are formed, built, disseminated, and mediated (Bryson, Crosby \& Bloomberg, 2014). They give meaning and identity to public service and are handled to create public value through public policy (Beck Jorgenson \& Bozeman, 2007; Andersen, Jorgensen, Kjeldsen, Pedersen, \& Vrangbaek, 2012; Bryson et al., 2014).

Creating public value implies the need for servants, citizens, policymakers, and partners to focus on what they are and what the imperative public values are, on practical ways to operationalize them and channel them towards achieving the desired results (Jacobs, 2014; Kalambokidis, 2014). It involves reconciling the interactions between actors and their different interests in the search for solutions in which the social, economic, and intangible benefits are higher than the related sacrifices (Papi, Bigoni, Bracci, \& Deidda, 2018).

The classic focus on managers, hierarchy, and bureaucracy gives way to inter-organizational and intersectoral relations and governance (Moore, 2014). In governance structures (Loeffler \& Bovaird, 2018; Galuszka, 2019), rigid vertical hierarchies are being replaced by flexible systems. The traditional patterns of governance are giving way to collective decision-making, in which priorities, activities, communications, and conventions are outlined through a consensus-building among the various actors (Oliveira, Pisa \& Augustinho, 2016; Galuszka, 2019). Thus, good public governance is no longer simply a matter of instructions, norms, or standards. It is structured with a strategic perspective, connecting at the micro-level (the institution's performance) with the macro-level (local, regional, and other stakeholders). It provides a strategic dialogue between managers, politicians (decision-makers), citizens, and partners, changing the approach from government to governance (Vignieri \& Bianchi, 2017).

The institutionalization and character of the participatory space become a relevant opportunity and the key to the success of public organizations and their services (Chohan \& Jacobs, 2017). Civil society, in general, labeled as the "plural sector," is destined to be the key actor in conducting the restoration of the balance between the public, private, citizens, and other actors in the renewal of constructive practices to replace destructive ones (Mintzberg, 2015). The plural sector formed by engagement among citizens (Mintzberg, 2015) and other actors has a significant impact on the process of formulating innovative policies (Galuszka, 2019) by channeling resources into the public interest and eliminating rhetoric (Chohan \& Jacobs, 2017; O'Brien, Golden \& Scott, 2018). This potential is anchored in the exploitation of knowledge and the generation of ideas by society in general, active, participatory and cooperative in deciding on innovative solutions (Oliveira et al., 2016; Galuszka, 2019).

Innovation gained space and evolved by addressing many problems in the public sphere, such as austerity measures, scenarios of financial constraints, society's growing expectation for better public services (Parahoo \& Ayyagari, 2019), scenarios of disasters, shocks, pandemics and other disruptions (Barasa, 2018; Rahman, 2020; Djalante et al., 2020; Berger et al., 2020). In this scenario, innovation is pointed as a promising path for the public sector in the fulfillment of its goals, mission, and objectives, while using its resources appropriately (Plimmer, Bryson \& Teo 2017; Parahoo \& Ayyagari, 2019).

The paradigm lies in the stimulus to increase connections and collaborations to innovate. There is an emerging need to remove the barriers to innovation created by closed and traditional systems in public organizations. Connecting closed systems through collaboration provides public sector entities with openness to new ideas and external stimuli to develop innovative solutions for public services (Smith, 2018; Parahoo \& Ayyagari, 2019; Gieske, Duijn \& Buuren, 2020). Therefore, public governance achieves better results with public policies, actions, innovations, services, or products co-created through an innovation ecosystem.

\subsection{Innovation Ecosystem}

The driving force for ecosystem interactions is the need to integrate and leverage resources that support co-creation through the unique experiences of service users (Parahoo \& Ayyagari, 2019). However, also and equally important, the innovation ecosystem as a hybrid arrangement of actors and networks for innovation, relies on technologies, cultural and sociological interactions between economic and non-economic agents (government, citizens, research institutions, for-profit or non-profit entities, for example) (Mercan \& Goktas, 2011; Santos et al., 2015). The innovation ecosystem also refers to the infrastructure necessary for actors to connect, aggregate, collaborate, and co-create innovations that generate value for and with society (Nambisan \& Nambisan, 2013; Santos, Kapoor, Tonelli, Weerakkody, Sousa, \& Souza, 2015; Smorodinskaya, Russell, Katukov, \& Still, 2017; Parahoo \& Ayyagari, 2019).

Ecosystems of innovation offer a conceptual map of co-creation (Nambisan \& Nambisan, 2013; Santos et al., 2015) in processes of innovation, generation of ideas and knowledge, which do not develop in isolation (Vega-Jurado et al., 2015; Smith, 2018; Parahoo \& Ayyagari, 2019). The services depend very much on their beneficiaries that provide information for the exploitation of innovation, functioning the ecosystem as a mechanism for integrating actors and 
providing resources for the necessary interactions, counting on some main facilitators: co-creation, co-production (Pestoff, 2014; Osborne, Radnor \& Strokosch, 2016) technology and organizational factors (Parahoo \& Ayyagari, 2019).

Co-creation and co-production of public value in a decision-making process gain strength as collaborative, horizontal and interactive approaches (Fung, 2015) becoming some of the pillars of innovation in public service (Collm \& Schedler, 2014; Smith, 2018; Parahoo \& Ayyagari, 2019) to improve the quality of services, achieve social goals, desired democratic values and resilience (Pestoff, 2014; Osborne et al., 2016; Keating, Campbell, Szoenyi, McQuistan, Nash, \& Burer, 2017).

Co-creation and co-production have a multidisciplinary use of concepts, broad political applicability, and are rarely distinguished (Brandsen \& Honingh, 2018; Loffler \& Bovaird, 2018). In this article, for better clarity and practical application, co-creation will be treated as distinct from the co-production of public value following the understanding of Torfing and Triantafillou (2016). However, they will be considered as complementary and simultaneous processes, which converge (Agger, Tortzen \& Rosenberg, 2018; Brandsen, Steen \& Verschuere, 2018) in what concerns the collaboration of citizens and others (Torfing \& Triantafillou, 2016) civil society actors, qualified by Mintzberg (2015) as a plural sector.

\subsection{Cocreation and the Innovation Ecosystem}

Co-creation is the process, through collaborative interactions, that stimulates mutual learning, exploration, and generation of knowledge, promotes new ideas and solutions, emerging to the problems experienced by society, neutralizing common wisdom and standard practices (Torfing, 2016; Torfing, Sørensen \& Røiseland, 2019; Ferlie, Pegan, Pluchinotta, \& Shaw, 2019).

Co-creation is not limited to the co-production of existing services, but is oriented towards creating innovative solutions to shared problems (Voorberg, Bekkers \& Tummers, 2015; Torfing \& Triantafillou, 2016; Ferlie et al., 2019; Torfing et al., 2019). It advocates active citizen involvement based on partnerships and common ground, where the parties contribute resources, especially in the form of knowledge. This is supported by the assumption that "ordinary citizens" have valuable knowledge and can help develop the quality of public services (Agger et al., 2018) as well as other actors (Torfing \& Triantafillou, 2016).

In the co-creation between government, citizens, and other actors, the literature distinguishes three main results: democracy (legitimacy and participation); efficiency (economy and better quality of social benefits); and innovation (new social and welfare solutions) (Brandsen et al., 2018). Co-creation aims the quality of public service. Citizens earn "more for less" (Andersen et al., 2012).

Co-creation provides a new mentality to society, focusing on promoting accountability, justice, and public sector legitimacy (Agger et al., 2018), adding value to collaboration, promoting change, and promoting social innovation participation and democracy (Voorberg et al., 2015). The inherent perspectives of the co-creating public value are that of the citizen who requires his or her needs to be met and that of the public administration who must use resources efficiently in order not to compromise the ability to add public value and protect prospects (O'Brien et al., 2018).

\subsection{Co-production}

Co-production is the improvement of existing public services. It involves cooperation among providers, users, and volunteers who apply their different resources, competencies, experiences, and capacities to the production and delivery of public services (Torfing \& Triantafillou, 2016). Co-production has its roots in traditional public administration, started in the mid-1970s by Elinor Ostrom, and gradually became relevant (Galuszka, 2019). "Co-production" at the time was applied to classic participatory models in which citizens exercised a potential effect on the provision of services (Ostrom, 1978; Whitaker, 1980).

However, the interpretation of the meaning of the term co-production is still diverse. Some authors approach co-production as the involvement of users and organizations (providers) of public services during a mechanism of exchange, in which they interact, produce and deliver the services (Pestoff, Brandsen \& Verschuere, 2012; Pestoff, 2014; Torfing \& Triantafillou, 2016). Other authors use the term as citizen involvement in decision-making (Bovaird \& Loeffler, 2013; Torfing \& Triantafillou, 2016).

Co-production maintains its traditional orthodoxy that servers are exclusively responsible for designing and providing services to citizens, who, in turn, only demand, consume and evaluate them (Osborne et al., 2016). The co-production of public value for Torfing e Triantafillou (2016) ends in an interactive process between providers and 
users of public services, with the application of their diverse and direct capacities and resources in the production and delivery of results. Thus, co-production differs from co-creation for some streams of studies, based on the scope of involvement of actors beyond service providers and their users (Torfing, 2016).

There are three levels of co-production: consumer co-production; participatory co-production; and improved co-production (Osborne \& Strokosch, 2013). Consumer co-production and participatory co-production work to improve the strategies and systems through which services are produced and made available (Osborne \& Strokosch, 2013). Improved co-production is very similar to co-creation because it promotes innovation and is inspired by the users of services and other parties (Torfing, 2016). At this time services are transformed, and future public needs and solutions to perverse problems are identified (Agger et al., 2018; Ferlie et al., 2019)

Criticisms of co-production also need to be known, in contrast to other studies that point to its aspects and its positive image (Aschhoff \& Vogel, 2018). Co-production is an illusory concept, a confusing word, in management and public policy. The managerial challenges are around the diversity of objectives and values of co-producers, often non-specialists in the subject (Osborne et al., 2016). Critics consider that the co-production environment has been used as a panacea for management and public governance problems (Aschhoff \& Vogel, 2018).

Difficulties in shared vision in agreements, mobilization, and selection of appropriate users, motivation for participation, and resource allocation are also critical to co-production (Jaspers \& Steen, 2017). The conflict of values, one of the most complex challenges in co-production, can lead public administrators to a situation of inertia in the face of difficult decisions, rational and irrational choices in environments of tensions and paradoxes between competing values. However, while there are problems and disadvantages, many other studies and authors argue that successful co-production provides better service in terms of innovation, legitimacy, and efficiency, compared to services produced by the public sector alone (Voorberg et al., 2015; Aschhoff \& Vogel, 2018; Agger et al., 2018; Ferlie et al., 2019).

These divergences demonstrate that the empirical reality of co-production needs to be assessed to see whether it is just passing rhetoric or a mechanism to redesign service management and a new "ethos" for the public sector. There is a perspective of change that is not evolutionary, but transformative about the roles of civil society and government for the satisfaction of the common good that can understand this reality of co-production (Nabatchi, Sancino \& Sicilia, 2017).

The inclusion of citizens in a co-production environment increases innovation and the responsiveness of the public sector (Aschhoff \& Vogel, 2018). In this context, public managers and public governance need to play, in addition to their other activities, the role of mediators and conciliators in the collaborative environment promoting an environment favorable to innovation and change for better results (Aschhoff \& Vogel, 2018). However, this requires new forms of organization, actions to stimulate collaborative innovation, and finally, emerging changes in traditional forms of governance (Torfing, 2016; Ferlie et al., 2019).

\section{Discussion}

For decades, disasters have caused damage to millions of people (Nkwunonwo et al., 2014). The average annual expenditure on natural disasters from 2006-2015 is around $\$ 137.6$ billion. In 2016 the economic losses from natural disasters reached $\$ 153.9$ billion (Guha-Sapir et al., 2017). More than 98 million people are affected by climate disasters in 2019 (Kihl, 2020). In the same year, at least 396 natural disasters with more than 11,000 fatal victims occurred globally, except for biological disasters. Events that were above the average of the last 10 years stipulated in 343 natural events per year. The most vulnerable and affected continent was Asia, with $40 \%$ of natural disasters, with $45 \%$ of deaths and $74 \%$ of people affected compared to globally (Centre for Research on the Epidemiology of Disasters - Cred, 2020).

If the human impact is considered, the event with more fatal victims (2,500 deaths) occurred in Europe (France, Belgium, and the Netherlands) with the summer heatwaves, followed by the flood in India during the heavy rains from July to October 2019 that led to 2,000 deaths. Similarly, the cyclone in Mozambique and Zimbabwe with 1,000 deaths, the storm Dorian in the United States, and the Bahamas with over 350 deaths. Analysis by continent shows 160 disasters in Asia, 89 events in Africa, 80 in the Americas, 57 in Europe, and 10 events in Oceania (Cred, 2020). These disasters are commonly considered natural at first because they have no triggering human action.

The intensity and impacts of these events have increased since the 20th century, with society at large becoming more and more vulnerable to these types of events (Glanz \& Onishi, 2011). Sometimes this disaster scenario is attributed to the consequences of the unsustainable development of humanity. Disasters are not entirely devoid of human actions (Guha-Sapir, 2016; Barasa, 2018). The primary outcome is of natural cause, such as earthquakes, insect or 
animal infestations, droughts, and storms. However, the intensity of the destructive consequences and negative impacts on the human factor can be of lesser or greater magnitude, depending on political regimes and policy construction imbued with the goals of making communities more resilient or less vulnerable (Barasa, 2018).

Disasters that are directly related to human actions are also very worrying. Disasters that occur due to conflicts of interest and unbalanced power relations, emerging diseases, climate change, and pollution, vulnerability and food insecurity, epidemics, and disease pandemics, cause severe damage as the causes, at first called natural. For example, and not in the same proportion, we have already experienced several pandemics or international public health emergencies such as the H1N1 pandemic in 2009, the Poliovirus and Ebola in 2014 in West Africa, the Zika Virus in 2016, Ebola in Congo in 2018 and the Coronavirus in 2019, 2020 and 2021, notified to the World Health Organization (WHO, 2021).

Observing the situation decreed on March 11 2020, by the World Health Organization regarding the global pandemic by the coronavirus (COVID-19), demonstrates how serious a pandemic catastrophe of rapid spread and severity can become, amid alarming levels of inaction (WHO, 2020). By May 8, there were 3,759,967 confirmed cases $(87,729$ new cases more than the previous day) and 259,474 deaths (5,429 new compared to the previous day (WHO, 2020a). As of April 13, 2021, the registered numbers were 136,291,755 (an increase of 567,849 new cases compared to the previous day) of confirmed cases from COVID-19, including 2,941,128 deaths (9,521 new cases compared to the previous day), reported WHO (WHO, 2021).

Poor governance must give way to adequate risk assessment and credible risk communications, multisectoral management task force, ensure basic support to the most vulnerable, judge public perceptions, achieve good governance, especially in middle-low income countries (Rahman, 2020). It is imperative to accelerate the integration of various global policy frameworks (Djalante et al., 2020), to prioritize a fair and equitable sharing of resources and knowledge to mitigate other risks, generating confidence and resilience of affected communities (Berger et al., 2020).

Effective disaster response requires the integration of short- and long-term actions at any level (global, national, regional, and local). There is a need for political commitment and integration of governments with actors with the potential to contribute to the creation of collective actions aimed at developing resilience to confront, combat, and adapt to the new pandemic context and future scenarios (Barasa, 2018; Rahman, 2020).

In pandemic situations, the development of resilience plays an expressive role in the resistance and adaptation of communities to the disaster environment. The adoption of good governance and management in these cases is essential to address any pandemic (Rahman, 2020), in addition to information, knowledge, funding, provision of services, medicines and equipment, health professionals, research and innovation (Legido-Quigley et al., 2020), leadership and timely, science-based decision-making (Djalante et al., 2020).

Thus, with the increasing incidence of disasters, governance efforts are being made to address the challenges and make structures more resilient (Nkwunonwo et al., 2014). However, some obstacles are noticeable such as the lack of synergy between society at large (citizens, research and innovation centers, companies, non-profit entities, and other actors) and local governance in the search for innovative and appropriate solutions to sustainable resilience (Wanie \& Ndi, 2018). Governments depend on the functioning of their governance structure. There are numerous occasions for governments to subsidize or contribute inappropriately to the adoption of actions to cool the risks of shocks, adapt to them, or minimize their consequences (Malalgoda et al., 2013; Wanie \& Ndi, 2018).

The existence of these dysfunctions in local governance can restrict resilience strategies, including institutional gaps, financial limitations, lack of knowledge of existing legislation, lack of commitment to local planning, unskilled and inadequate labor. Notably, minimally adequate governance requires effective decentralization, autonomy, transparency, accountability, flexibility and responsiveness, innovation, inclusion, and society's participation at the planning and management levels (Wanie \& Ndi, 2018).

Political inertia, constant government exchange, and disproportionate power relations need to be addressed (Wanie \& Ndi, 2018), as well as barriers attributed to lack of data, weak awareness and participation of the population, disability in risk knowledge, mitigation policies and government policies (Nkwunonwo et al., 2014). Political pressure, power relations, opportunism, and bribery often annulled regulations, planning instruments, and investments (Malalgoda et al., 2013). Factors that configure corruption are also a major challenge in creating a resilient scenario (Malalgoda et al., 2013; Nkwunonwo et al., 2014; Keating et al., 2017).

These and other barriers need to be addressed to reflect and strengthen resilience to recurring natural disasters, disasters accentuated by human action, pandemics, and shocks. A roadmap for sustainable resilience depends on a 
good governance structure (Carpenter, Westley \& Turner, 2005; Keating et al., 2017). Good governance requires a change in the conception of how political authority is exercised, its multiple actors, and establishing limitations to government as a single central actor (Lynn, 2010; Ehnert et al., 2018). The government's single source of traditional authority was challenged as early as the mid-1970s because the government itself was no longer sufficiently capable, competent, and legitimate (Kooiman, 2003; Ehnert et al., 2018).

There is no sovereignty in authority, and there are multiple actors for each area of government intervention. In this respect, governance proposes to redesign the boundaries between the state and society at large (Rhodes, 1997; Lynn, 2010), adopting the conceptual perspective of collaboration between the various actors of society, such as citizens, scientific and technological institutions, research centers, public and private institutions, the third sector and other partners willing to share knowledge and ideas to solve the problems that plague society (Ehnert et al., 2018).

In this scenario, local public governance (and other levels) can be a response to communities dealing with dynamic and complex challenges that need to be structured and managed. Sound governance seeks development and resilience in shock environments (Vignieri \& Bianchi, 2017, p. 10). This implies changing the way local actors design their relationships. In the practice of public governance, these relationships seem to have been left out of the equation, because governance focuses mainly on rules and norms, but little with how actions structure the processes of interaction and decision-making among the actors involved in a common problem (Vignieri \& Bianchi, 2017; Borie et al., 2019). The practice of public governance needs to be reviewed to benefit the cooperation environment between actors in solving complex problems (Wanie \& Ndi, 2018; Ricciardelli et al., 2018).

The literature review demonstrates that resilience emerges as a model of transition to a desirable state, in addition to avoiding or preparing for shocks, pandemics, disasters or disruptions, but also as an opportunity to reflect and rethink communities and redesign them for and with the participation of society (Ricciardelli et al., 2018). Thus, future public service reform efforts need to be spent to create new possibilities for better and more inclusive public outcomes (Hambleton, 2019). With this perspective on how to make communities more resilient and responsive to pandemics, disasters, or other disruptions, this study sought to explore and explain the theoretical evidence that resilience capacity can be positively influenced by good public governance that encourages the innovation ecosystem and stimulates value co-creation and co-production. In a scenario where the various actors can and do have the potential to contribute and support governance in the search for solutions to the problems faced.

Public governance can be understood as a structure of rules, standards, and institutions; and an arrangement also prepared to act in complex environments. However, it also needs to combine political, management, scientific, and technological mechanisms to create public value for and with society, through processes of orientation, deliberation, decision making, creation and production of effective policies and consolidated results. This process requires public governance to act strategically in the agency of guidelines for support, organization, articulation, integration, and interactions between government, citizens, and other civil society actors in general, in the creation of value. The other actors may be scientific, technological and research institutions, for-profit or non-profit entities, and other types of organizations.

The process of creating public value is a retro-food and collaborative cycle that needs to rely on robust public governance, prepared for the articulation and formation of strategic alliances around a common problem and of public interest. The cooperative connection between stakeholders and governance aims to unite experiences, ideas, technologies, scientific and technical solutions, distinct resources, financial and non-financial, with the objective of better results and resilience to society. Such an arrangement, as several authors conceptualize, can be called an innovation ecosystem that is conceptualized as the necessary infrastructure for stakeholders to promote cultural and sociological interactions, to connect, aggregate, collaborate, co-create innovations and support co-production of value to and with society (Mercan \& Goktas, 2011; Nambisan \& Nambisan, 2013; Santos et al., 2015; Smorodinskaya et al., 2017; Parahoo \& Ayyagari, 2019)

The theoretical review on the topics covered, allows in a process logic, interactive and constructive steps, to propose a theoretical-scientific framework, on an experimental basis for future empirical tests. The model outlines the generation of public value through governance and its tripod (Government, Citizens, and other actors), sustained and connected in an innovation ecosystem that promotes co-creation, co-production, and value co-evaluation. This model demonstrates a possible propensity to generate better results, contribute to the search for resilience in environments of pandemics, shocks, disasters, or disruptions. Such a structure can be seen in Figure 1. 


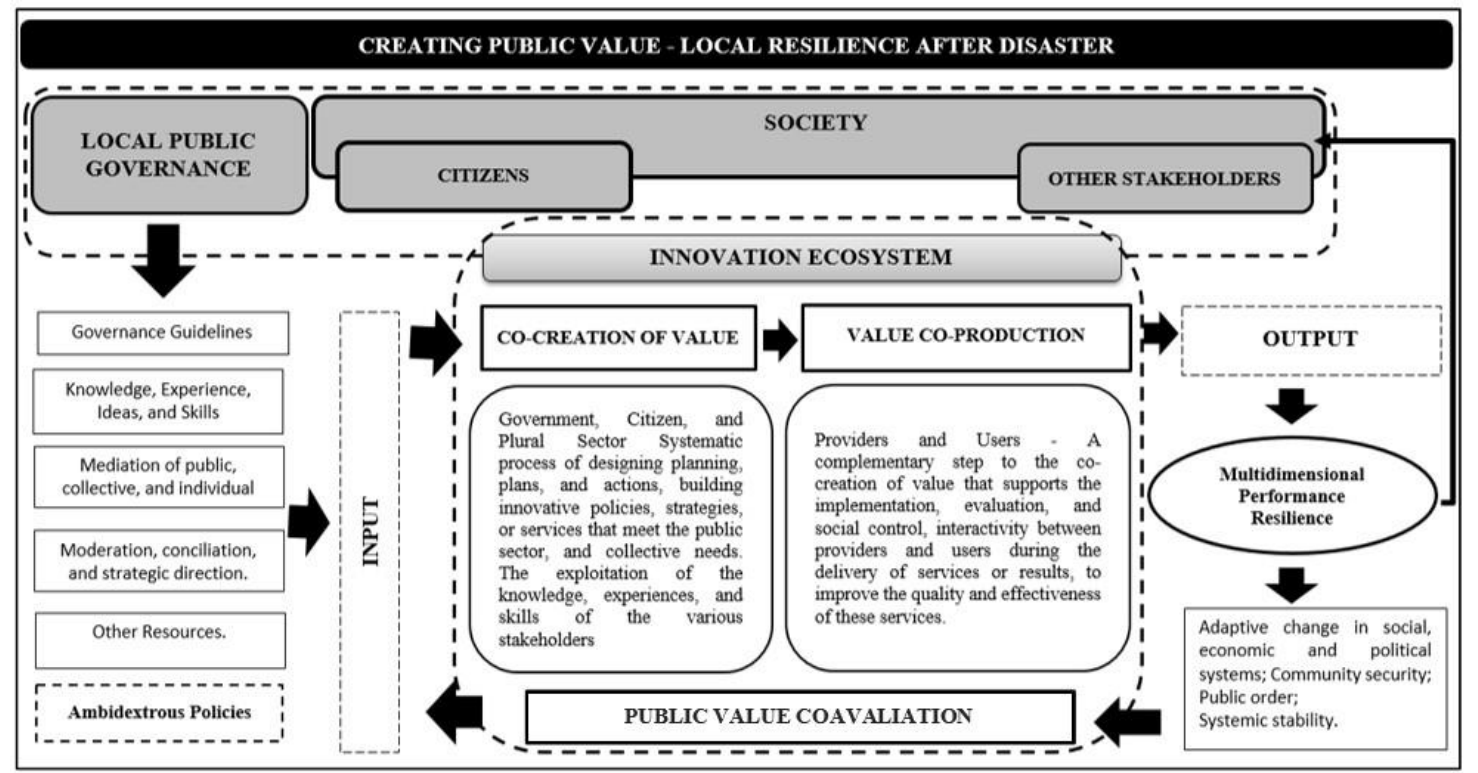

Figure 1. Theoretical framework

Source: Prepared by the authors from the literature review

There is evidence in the literature that the innovation ecosystem, co-creation, and value co-production can improve the ability to innovate solutions, resist, absorb, and recover from shocks. However, they also have challenges to overcome. It is necessary to overcome a greater conceptual and practical clarity to co-creation and co-production that are often used in the literature as synonyms, as antagonistic and even interchangeable. Because of these factors, this article, in proposing the overcoming of concepts, presents the framework as a dynamic and complementary logic between the two terms, by distinguishing co-creation from value co-production, accompanying Torfing (2016).

Co-creation is defined as a technique with value in itself, operated in a strategic, creative, and innovative environment (innovation ecosystem). Through this technique, the collective problems that plague society are brought into the discussion. A technique that stimulates cooperation, the exchange of experiences, ideas, technologies, technical and scientific knowledge. The entities that need to participate in this cooperative process: governance as a moderator; citizens; technological and research centers; companies; profit or non-profit entities; and others interested in contributing. Co-creation allows for a thorough investigation of the problem, exploitation of the knowledge, and design of the solution. The co-creation process includes the study, design, planning, and construction of the solution to the collective problem discussed. The product of this (technical) process is the public policy co-created, coherent, and innovative concerning the deficiencies the society faces, which will be co-produced.

We proposed that co-production is distinct but complementary to co-creation. Co-production is conceived as the phase of implementation, delivery, evaluation, and feedback of the co-creation process. It involves providers and users of public services and innovations in the co-creation environment. Its result or final product is the effectiveness of the results of the policy implemented. This is the moment in which the user at the disposal of this public policy will perceive the public value created and solve the problem experienced by society. As some authors have already argued, co-production is about the participation of service users during a mechanism of exchange, service delivery, and feedback (Chathoth, 2013; Brandsen \& Honingh, 2018).

\section{Concluding Remarks}

This article contributes to the knowledge about public governance and local resilience by presenting, through the literature review, a discussion on the relationship between public governance, the innovation ecosystem, co-creation and co-production, impacting local resilience in environments pandemics, shocks, disasters or disturbances.

If well designed, governance, the innovation ecosystem, co-creation, and co-production can represent support mechanisms for generating and implementing innovation in the public sector, achieving better results for society, including improving resilience in troubled environments, from pandemics, disasters to shocks. Literature discussions 
agree that flexible and resilient governance structures, with leadership capacity, are needed to explore the collaborative environment and dialogic relations between government and society. There is a need to undertake emerging patterns of interaction and use of collective intelligence, intellectual capital, research, innovative technologies, and strategies, particularly in these unpredictable and non-linear environments. Facts that theoretically justify the proposed framework as a potential source of knowledge generation, innovation, and strategic advantage for public sector organizations. The model needs to be empirically tested to prove its effectiveness and the need to adapt to the researched context.

The article contributes to the literature by presenting a proposal for a theoretical framework containing the relationship between the constructs public governance, innovation ecosystem, co-creation, co-production and local resilience, as suggested by the researched literature. The practical contribution of the article is in addressing the themes in order to encourage managers to become interested in the agenda, which is important for public management in the current global context, given the effects of the COVID 19 pandemic and the incidence of major disasters proportions. The study has the limitation of being a perception and a generic theoretical path, not taking into account specific aspects of the environment. For future research, it is suggested to carry out empirical research with the application of the theoretical model, proposed here, in different environments. Comparison of results after applying the model is also recommended for future research.

\section{References}

Agger, A., Tortzen, A., \& Rosenberg, C. (2018). Hvilken vardi skaber vi med samskabelse. Professionshøjskolen Absalon. Retrieved from https://rucforsk.ruc.dk/ws/portalfiles/portal/63109818/Hvilken_vaerdi_skaber_vi_med_samskabelse_1_.pdf

Alexander, D. (2003). Terrorism, disasters, and security. Prehospital and Disaster Medicine, 18(3), 165-169. https://doi.org/10.1017/S1049023X0000100X

Andersen, L. B., Jorgensen, T. B., Kjeldsen, A. M., Pedersen, L. H., \& Vrangbaek, K. (2012). Public value dimensions: Developing and testing a multi-dimensional classification. International Journal of Public Administration, 35(11), 715-728. https://doi.org/10.1080/01900692.2012.670843

Aschhoff, N., \& Vogel, R. (2018). Value conflicts in co-production: governing public values in multi-actor settings. International Journal of Public Sector Management, 31(7), 775-793. https://doi.org/10.1108/IJPSM-08-2017-0222

Barasa, B. (2018). Increased incidences, intensity and scope of disasters: Manifestation of unsustainable development practices. Environment Pollution and Climate Change, 2(2), 1-9. https://doi.org/10.4172/2573-458X.1000154

Beck Jorgensen, T., \& Bozeman, B. (2007). Public values: an inventory. Administration \& Society, 39(3), 354-381. https://doi.org/10.1177/0095399707300703

Berger, Z. D., Evans, N. G., Phelan, A. L., \& Silverman, R. D. (2020). Covid-19: control measures must be equitable and inclusive. The BMJ, 368(m1141), 1-2. https://doi.org/10.1136/bmj.m1141

Bhamra, R., Dani, S., \& Burnard, K. (2011). Resilience: the concept, a literature review and future directions. International Journal of Production Research, 49(18), 5375-5393. https://doi.org/10.1080/00207543.2011.563826

Bilotta, G. S., Milner, A. M., \& Boyd, I. (2014). On the use of systematic reviews to inform environmental policies. Environmental Science \& Policy, 42, 67-77. https://doi.org/10.1016/j.envsci.2014.05.010

Borie, M., Pelling, M., Ziervogel, G., \& Hyams, K. (2019). Mapping narratives of urban resilience in the global south. Global environmental change, 54, 203-213. https://doi.org/10.1016/j.gloenvcha.2019.01.001

Bovaird, T., \& Loeffler, E. (2013). We're all in this together: harnessing user and community co-production of public outcomes. In Birmingham: Institute of Local Government Studies. University of Birmingham, 1-13. Retrieved

from https://www.birmingham.ac.uk/Documents/college-social-sciences/government-society/inlogov/publications/20 13/chapter-4-bovaird-loeffler.pdf

Brandsen, T., \& Honingh, M. (2018). Definitions of Co-production and Co-creation. In Co-production and co-creation (pp. 9-17). Routledge. https://library.oapen.org/bitstream/handle/20.500.12657/25001/9781138700116_text.pdf?sequence=1\#page=23 
Brandsen, T., Steen, T., \& Verschuere, B. (2018). Co-creation and co-production in public services: Urgent issues in practice and research. In Co-production and co-creation (pp. 3-8). Routledge. Retrieved from https://library.oapen.org/bitstream/handle/20.500.12657/25001/9781138700116_text.pdf?sequence=1\#page=23

Bryson, J. M., Crosby, B. C., \& Bloomberg, L. (2014). Public value governance: Moving beyond traditional public administration and the new public management. Public Administration Review, 74(4), 445-456. https://doi.org/10.1111/puar.12238

Campbell, B. C. (2014). The growth of American government, revised and updated edition: governance from the cleveland era to the present. Indiana University Press.

Carpenter, S. R., Westley, F., \& Turner, M. G. (2005). Surrogates for resilience of social-ecological systems. Ecosystems, 8(8), 941-944. https://doi.org/10.1007/s10021-005-0170-y

Castelnovo, W., Misuraca, G., \& Savoldelli, A. (2016). Smart cities governance: The need for a holistic approach to assessing urban participatory policy making. Social Science Computer Review, 34(6), 724-739. https://doi.org/10.1177/0894439315611103

Chathoth, P., Altinay, L., Harrington, R. J., Okumus, F., \& Chan, E. S. (2013). Co-production versus co-creation: A process based continuum in the hotel service context. International Journal of Hospitality Management, 32, 11-20. https://doi.org/10.1016/j.ijhm.2012.03.009

Chohan, U. W., \& Jacobs, K. (2017). Public Value as Rhetoric: a budgeting approach. International Journal of Public Administration, 41(15), 1217-1227. https://doi.org/10.1080/01900692.2017.1373673

Collm, A., \& Schedler, K. (2014). Strategies for introducing organizational innovation to public service organizations. Public Management Review, 16(1), 140-161. https://doi.org/10.1080/14719037.2013.822528

CRED, Centre for Research on the Epidemiology of Disasters. (2020). CRED Crunch 58 - Disaster Year in Review (2019). Retrieved from https://cred.be/sites/default/files/CC58.pdf

Djalante, R., Shaw, R., \& DeWit, A. (2020). Building resilience against biological hazards and pandemics: COVID-19 and its implications for the Sendai Framework. Progress in Disaster Science, 100080. https://doi.org/10.1016/j.pdisas.2020.100080

Ehnert, F., Kern, F., Borgström, S., Gorissen, L., Maschmeyer, S., \& Egermann, M. (2018). Urban sustainability transitions in a context of multi-level governance: A comparison of four European states. Environmental Innovation and Societal Transitions, 26, 101-116. https://doi.org/10.1016/j.eist.2017.05.002

Ferlie, E., Pegan, A., Pluchinotta, I., \& Shaw, K. (2019). Co-Production and Co-Governance: Strategic Management, Public Value and Co-Creation in the Renewal of Public Agencies across Europe. Retrieved from http://cogov.eu/wp-content/uploads/2020/05/COGOV-DeliverableWP1-1.pdf

Frederickson, H. G. (2005). Whatever happened to public administration? Governance, governance everywhere. The Oxford Handbook of Public Management, 282-304. Retrieved from http://citeseerx.ist.psu.edu/viewdoc/download?doi=10.1.1.537.8624\&rep=rep1\&type=pdf

Fung, A. (2015). Putting the public back into governance: The challenges of citizen participation and its future. Public Administration Review, 75(4), 513-522. https://doi.org/10.1111/puar.12361

Galuszka, J. (2019). What makes urban governance co-productive? Contradictions in the current debate on co-production. Planning Theory, 18(1), 143-160. https://doi.org/10.1177/1473095218780535

Gieske, H., Duijn, M., \& Van Buuren, A. (2020). Ambidextrous practices in public service organizations: innovation and optimization tensions in Dutch water authorities. Public Management Review, 22(3), 341-363. https://doi.org/10.1080/14719037.2019.1588354

Glanz, J., \& Onishi, N. (2011). Japan's strict building codes saved lives. New York Times, 11 March 2011. Retrieved from https://www.nytimes.com/2011/03/12/world/asia/12codes.html

Guha-Sapir, D., Hoyois, P., Wallemacq, P., \& Below, R. (2016). Annual disaster statistical review 2016: The numbers and trends. Brussels, Belgium: Centre for Research on the Epidemiology of Disasters. Retrieved from http://lib.riskreductionafrica.org/bitstream/handle/123456789/1141/annual\%20disaster\%20statistical\%20review $\% 202011 . \% 20$ the $\% 20$ numbers\%20and\%20trends.pdf?sequence $=1$

Hambleton, R. (2019). The New Civic Leadership: Place and the co-creation of public innovation. Public Money \& Management, 39(4), 271-279. https://doi.org/10.1080/09540962.2019.1592908 
Hirst, P. (2000). Democracy and governance. In Debating governance: authority, steering, and democracy, Jon Pierre (pp. 13-35). Oxford: Oxford University Press.

Jacob, T., Sørensen, E., \& Røiseland, A. (2019). Transforming the public sector into an arena for co-creation: Barriers, Drivers, Benefits, and Ways Forward. Administration \& Society, 51(5), 795-825. https://doi.org/10.1177/0095399716680057

Jacobs, L. (2014). The contested politics of public value. Public Administration Review, 74(4), 480-494. https://doi.org/10.1111/puar.12170

Jaspers, S., \& Steen, T. (2017). Value dilemmas and coping strategies in the co-production of social care: a qualitative study. Conference Proceedings of the IIAS Study Group on Co-production of Public Services (pp. 321-347), Washington, DC. Retrieved from https://lirias.kuleuven.be/1867561?limo=0

Kalambokidis, L. (2014). Creating public value with tax and spending policies: the view from public economics. Public Administration Review, 74(4), 519-526. https://doi.org/10.1111/puar.12162

Keating, A., Campbell, K., Szoenyi, M., McQuistan, C., Nash, D., \& Burer, M. (2017). Development and testing of a community flood resilience measurement tool. Natural Hazards Earth System Science, 17, 77-101. https://doi.org/10.5194/nhess-17-77-2017

Kernaghan, K., Borins, S. F., \& Marson, D. B. (2000). The new public organization. Institute of Public Administration of Canada.

Kihl, L. (2020). Changement Climatique: Un facteur de risqué plutôt qu'une cause directe. In Les catastrophes climatiques ont affecté près de 98 millions de personnes. LE SOIR Bruxelles, 14 Jan 2020. Retrieved from https://reliefweb.int/sites/reliefweb.int/files/resources/200114_Catastrophes-1.pdf

Kooiman, J. (2003). Governing as Governance. SAGE Publications, London. https://doi.org/10.4135/9781446215012

Legido-Quigley, H., Mateos-García, J. T., Campos, V. R., Gea-Sánchez, M., Muntaner, C., \& McKee, M. (2020). The resilience of the Spanish health system against the COVID-19 pandemic. The Lancet Public Health. https://doi.org/10.1016/S2468-2667(20)30060-8

Loeffler, E., \& Bovaird, T. (2018). 20 Assessing the Effect of Co-Production on Outcomes, Service Quality and Efficiency. Co-Production and Co-Creation, 269. Retrieved from https://library.oapen.org/bitstream/handle/20.500.12657/25001/9781138700116_text.pdf?sequence=1\#page=28 3

Lynn, L. E. (2010). Has governance eclipsed government?. In R. F. Durant (Ed.), The Oxford handbook of American bureaucracy (pp. 669-690). Oxford University Press, Oxford. https://doi.org/10.1093/oxfordhb/9780199238958.003.0028

Malalgoda, C., Amaratunga, D., \& Haigh, R. (2013). Creating a disaster resilient built environment in urban cities. International Journal of Disaster Resilience in the Built Environment. https://doi.org/10.1108/17595901311299017

Manyena, S. B. (2006). Rural local authorities and disaster resilience in Zimbabwe. Disaster Prevention and Management, 15(5), 810-820. https://doi.org/10.1108/09653560610712757

Mercan, B., \& Goktas, D. (2011). Components of innovation ecosystems: a cross-country study. International Research Journal of Finance and Economics, 76(16), 102-112. Retrieved from http://blog.ub.ac.id/arifhidayat/files/2012/06/Components-of-Innovation-Ecosystems.pdf

Milward, H. B., \& Provan, K. G. (2000). Governing the hollow state. Journal of Public Administration Research and Theory, 10(2), 359-380. https://doi.org/10.1093/oxfordjournals.jpart.a024273

Mintzberg, H. (2015). Rebalancing society, Radical renewal beyond left, right, and center. Retrieved from www.mintzberg.org.

Moore, M. H. (1995). Creating Public Value: Strategic Management in Government. Cambridge, MA: Harvard University Press.

Moore, M. H. (2014). Public Value Accounting: Establishing the Philosophical Basis. Public Administration Review, 74(4), 465-477. Retrieved from https://doi.org/10.1111/puar.12198 
Myers, R., Larson, A. M., Ravikumar, A., Kowler, L. F., Yang, A., \& Trench, T. (2018). Messiness of forest governance: How technical approaches suppress politics in REDD and conservation projects. Global Environmental Change, 50, 314-324. https://doi.org/10.1016/j.gloenvcha.2018.02.015

Nabatchi, T., Sancino, A., \& Sicilia, M. (2017). Varieties of participation in public services: The who, when, and what of coproduction. Public Administration Review, 77(5), 766-776. https://doi.org/10.1111/puar.12765

Nambisan, S., \& Nambisan, P. (2013). Engaging citizens in co-creation in public services. IBM Center Bus. Government. Retrieved

from https://icma.org/sites/default/files/305952_Engaging\%20Citizens\%20in\%20Co-Creation\%20in\%20Public\%20S ervice.pdf

Nkwunonwo, U. C., Whitworth, M., Baily, B., \& Inkpen, R. (2014). The development of a simplified model for urban flood risk mitigation in developing countries. In Vulnerability, uncertainty, and risk: quantification, mitigation, and management (pp. 1116-1127). Retrieved from https://ascelibrary.org/doi/abs/10.1061/9780784413609.113

O'Brien, A., Golden, W., \& Scott, M. (2018). Public values on the cusp of change, the journey from consultation to collaboration. In Proceedings of the 11th International Conference on Theory and Practice of Electronic Governance (pp. 685-686). https://doi.org/10.1145/3209415.3209450

Oliveira, A. G. D., Pisa, B. J., \& Augustinho, S. M. (2016). Gestão e governança pública: aspectos essenciais. Retrieved from http://repositorio.utfpr.edu.br/jspui/handle/1/2050

Osborne, S. P. (2006). The new public governance?. Public Management Review, 8(3), 377-387. https://doi.org/10.1080/14719030600853022

Osborne, S. P. (2010). The New Public Governance? Emerging Perspectives on the Theory and Practice of Public Governance. Routledge, London. Retrieved http://www.revistascientificas.udg.mx/index.php/JPGPA/article/view/3423

Osborne, S. P., \& Strokosch, K. (2013). It takes Two to Tango? Understanding the Co-production of Public Services by Integrating the Services Management and Public Administration Perspectives. British Journal of Management, 24, 31-47. https://doi.org/10.1111/1467-8551.12010

Osborne, S. P., Radnor, Z., \& Strokosch, K. (2016). Co-production and the co-creation of value in public services: a suitable case for treatment?. Public Management Review, 18(5), 639-653. https://doi.org/10.1080/14719037.2015.1111927

Ostrom, E. (1978). Citizen Participation and Policing: What Do We Know?. Journal of Voluntary Action Research, 7(1-2), 102-108. https://doi.org/10.1177/089976407800700110

Papi, L., Bigoni, M., Bracci, E., \& Deidda G. E. (2018). Measuring public value: a conceptual and applied contribution to the debate. Public Money \& Management, 38(7), 503-510. https://doi.org/10.1080/09540962.2018.1439154

Parahoo, S. K., \& Ayyagari, M. (2019). Innovation Ecosystem. In Global encyclopedia of public administration, public policy, and governance (pp. 1-6). New York, Springer.

Pestoff, V. (2014). Collective action and the sustainability of co-production. Public Management Review, 16(3), 383-401. https://doi.org/10.1080/14719037.2013.841460

Pestoff, V., Brandsen, T., \& Verschuere, B. (2012). New public governance, the third sector and co-production. New York, Routledge.

Plimmer, G., Bryson, J., \& Teo, S. T. T. (2017). Opening the black box: the mediating roles of organisational systems and ambidexterity in the hrm-performance link in public sector organisations. Personnel Review, 46(7), 1434-1451. https://doi.org/10.1108/PR-10-2016-0275

Rahman, M. M. (2020). Psychosocial and socioeconomic crisis in Bangladesh due to COVID-19 pandemic: a perception-based assessment. Frontiers in Public Health, 8(341), 1-17. https://doi.org/10.3389/fpubh.2020.00341

Rhodes, R. A. W. (1997). Understanding governance: policy networks, governance, reflexivity and accountability. Buckingham: Open University Press. 
Ricciardelli, A., Manfredi, F., \& Antonicelli, M. (2018). Impacts for implementing SDGs: sustainable collaborative communities after disasters. The city of Macerata at the aftermath of the earthquake. Corporate Governance, 18(4), 594-623. https://doi.org/10.1108/CG-01-2018-0027

Rodin, J. (2014). The resilience dividend: being strong in a world where things go wrong, hachette bookgroup. Public Affairs, New York.

Saito-Jensen, M. (2015). Theories and Methods for the Study of Multi-level Environmental Governance. In Co-producing Knowledge, Government and Society (pp. 16-18). Center for International Forestry Research.

Sanders, A. J. P., Hyldmo, H. S., Prasti, R. D., Ford, R. M., Larson, A. M., \& Keenan, R. J. (2017). Guinea pig or pioneer: translating global environmental objectives through to local actions in Central Kalimantan, Indonesia's REDD+ pilot province. Global Environmental Change, 42, 68-81. https://doi.org/10.1016/j.gloenvcha.2016.12.003

Santos, H. R., Kapoor, K., Tonelli, D. F., Weerakkody, V., Sousa, D., \& De Souza Bermejo, P. H. (2015). Collaborative Innovation in the Public Sector a Case of the Brazilian Federal Government. In International Conference on Electronic Government and the Information Systems Perspective (pp. 132-145). Springer. Retrieved from https://link.springer.com/chapter/10.1007/978-3-319-22389-6_10

Smith, S. K. (2018). Fostering innovation in the public sector: An organizational innovation ecosystem maturity model. Retrieved

from https://era.library.ualberta.ca/items/73254988-2d00-40e9-9bbe-adb04ca2f875/view/1b29649e-7ccb-4fd2-8e73261e85253aeb/Kubinec\%20Smith\% 20Capstone.pdf

Smorodinskaya, N., Russell, M., Katukov, D., \& Still, K. (2017). Innovation ecosystems vs. innovation systems in terms of collaboration and co-creation of value. In Proceedings of the 50th Hawaii international conference on system sciences (pp. 5243-5254). Retrieved from http://hdl.handle.net/10125/41798

Stoker, G. (1998). Governance as theory: five propositions. International Social Science Journal, 50(155), 17-28. Retrieved from http://www.elfhs.ssru.ac.th/pokkrong_ma/pluginfile.php/50/block_html/content/Stoker\%202002,\%20Governan ce\%20as\%20theory,\%20five\%20propositions.pdf

Torfing, J. (2016). Collaborative innovation in the public sector. Washington: Georgetown University Press.

Torfing, J., \& Triantafillou, P. (2016). Enhancing public innovation by transforming public governance. Cambridge: Cambridge University Press

Van Thiel, S., Pollitt, C., \& Homburg, V. (2007). New public management in Europe. Basingstoke: Palgrave Macmillan.

Vega-Jurado, J., Juliao-Esparragoza, D., Paternina-Arboleda, C. D., \& Velez, M. C. (2015). Integrating technology, management and marketing innovation through open innovation models. Journal of Technology Management \& Innovation, 10(4), 85-90. https://doi.org/10.4067/S0718-27242015000400009

Vignieri, V., \& Bianchi, C. (2017). Enhancing the Governance of Local Areas through Dynamic Performance Management. PhD Tesis. University of Palermo, Department of Political Science and International Relationships, Ph.D. Program in Model Based Public Planning, Policy Design, and Management, SSD SECS-P/07 - Business \& Public Management.

Voorberg, W., Bekkers, V. J., \& Tummers, L. G. (2015). A Systematic Review of Co-Creation and Co-Production: Embarking on the Social Innovation Journey. Public Management Review, 17(9), 1333-1357. https://doi.org/10.1080/14719037.2014.930505

Wanie, C. M., \& Ndi, R. A. (2018). Governance issues constraining the deployment of flood resilience strategies in Maroua, Far North Region of Cameroon. Disaster Prevention and Management: An International Journal, 27(2), 175-192. https://doi.org/10.1108/DPM-12-2017-0300

Whitaker, G. (1980). Co-production: Citizen participation in service delivery. Public Administration Review, 40(3), 240-246. https://doi.org/10.2307/975377

WHO. (2020). Press Conference of WHO about COVID-19. Retrieved from https://www.who.int/docs/default-source/coronaviruse/transcripts/who-audio-emergencies-coronavirus-press-co nference-full-and-final-11 mar2020.pdf?sfvrsn=cb432bb3_2 
WHO. (2020a). Coronavirus disease (COVID-19) Situation Report- 111 Data as received by WHO from national $\begin{array}{lllllll}\text { authorities } & \text { by } & 10: 00 & \text { CEST, } & \text { May } & \text { Retrieved from }\end{array}$ https://www.who.int/docs/default-source/coronaviruse/situation-reports/20200510covid-19-sitrep-111.pdf?sfvrs $\mathrm{n}=1896976 \mathrm{f} \_2$

WHO. (2021). Coronavirus (COVID-19) Dashboard, as of 4:13pm CEST, 13 April 2021. Retrieved from https://covid19.who.int/

\section{Copyrights}

Copyright for this article is retained by the author(s), with first publication rights granted to the journal.

This is an open-access article distributed under the terms and conditions of the Creative Commons Attribution license (http://creativecommons.org/licenses/by/4.0/). 